CSL Ebeling, Grønn, Hauge \& Santos (eds.) Corpus-based Studies in Contrastive Linguistics, Oslo Studies in Language 6(1), 2014. 201-228. (ISSN 1890-9639)

http://www. journals.uio.no/osla

\title{
POSTVERBAL SUBJECTS IN OLD ENGLISH AND OLD FRENCH
}

\author{
CHRISTINE MEKLENBORG SALVESEN \& KRISTIN BECH \\ University of Oslo
}

A B S TRACT

Both Old English and old French are commonly described as V2 languages. We investigate the position of the postverbal subject based on a corpus of medieval texts with respect to syntax and information structure. Our main findings are that information structure plays a more important role in old English than in Old French.

\section{[1] INTRODUCTION}

This paper investigates subjects in postverbal position in Old English (OE, 700 ca. 1100) and Old French (OF, 842 - ca. 1350) against the backdrop of the verbsecond (V2) phenomenon (for OE see among others Pintzuk $(1993,1999)$; Haeberli (2000, 2002); Pintzuk \& Haeberli (2008); Walkden (2012, To appear)); for OF, see among others Thurneysen (1892); Foulet (1930); Adams $(1987,1989)$; Roberts (1993); Vance (1997); Labelle (2006). We show that postverbal pronominal subjects are adjacent to the finite verb in both languages. Furthermore, we argue that postverbal DP subjects do not evacuate the expanded vP in either language. As for information structure, both languages are sensitive to weight, but information value plays a more prominent role in $\mathrm{OE}$ than in OF.

Verb-second word order in OE and OF is illustrated in examples (1) and (2). In (1), the adverbial prepositional phrase (PP) on bisum geare 'in this year' precedes the finite verb heold 'held', which again is followed by the subject se cyng Henri 'king Henry'. In the OF example in (2), the nominal adverb toute cele semeinne et l'autre apres 'all week, and the week after' is in clause-initial position, and the subject boorz 'Bors' follows the finite verb demora 'stayed'.

(1) On pisum geare heold se cyng Henri his hired to Cristesmæssan æt in this year held the king Henry his household at Christmas at Westmynstre

Westminster

'In this year, at Christmas, king Henry held his household at Westminster'

(ChronE 35)

[1] In all examples, the finite verb appears in italics. 
(2) toute cele semeinne et l' autre apres demora boorz en l' ostel all this week and the other after stayed Bors in the household le roi artu entre lui et sa compaignie the king Arthur between him and his company 'All week, and the week after, Bors stayed in the household of king Arthur together with his men'

(MoA 93671)

The V2 constraint is found in all modern Germanic languages with the noteworthy exception of Modern English. As we saw in (1) and (2), it implies that the finite verb is found in second position of the clause, regardless of which element is in first position. The verb may be preceded by the subject as in (3). If, however, an $\mathrm{XP}$ other than the subject precedes the finite verb, as in (4), the subject occurs postverbally.

(3) Det er kaldt i dag

it is cold in day

'It is cold today'

(Norwegian)

(4) I dag er det kaldt

in day is it cold

'Today it is cold'

(Norwegian)

However, both $\mathrm{OE}$ and $\mathrm{OF}$ also have numerous non-V2 sentences that apparently contradict their status as V2 languages, as in (5) and (6), where the verb occurs in third position. In addition, both present-day languages are SVO languages. In this respect, English is unique among the Germanic languages and French unique among the Romance languages.

(5) Et quant il l'aperçoit, il est trop dolenz

and when he it-discovers he is too suffering

'And when he discovers this, he becomes very sad'

(Tr 273)

(6) ba deor hi hatað hranas

the deer they call reindeer

'they call the deer reindeer'

(Or 15)

In Bech \& Salvesen (2014), we analyzed clauses with a preverbal subject, and we showed that despite the superficial similarities between $\mathrm{OE}$ and $\mathrm{OF}$, the languages are fundamentally different. First, declarative main clauses in OF have the finite verb in a structurally high position, whereas $\mathrm{OE}$ main clauses may have the verb in a high or a low position. This variation in OE makes the language difficult to analyze, as it is supposed that the grammar is mixed (Lightfoot 1979,1999), so that some clauses are head-final, others head-initial. In many cases it is obvious that 
the finite verb sits in a very low position (e.g. verb-final) (7); in other cases it is impossible to tell whether the verb sits high or low in the structure (8).

Monigre geara tida ofer ealle Breotone ic
many.GEN.PL year.GEN.PL time.GEN.PL over all Britain I
'For many a year I have been a fugitive throughout all Britain'
Forðam ic ðe loere pæt pu fleo and beorge pinum life.
therefore I you teach that you flee and save your life
'Therefore I counsel you to flee, and save your life'

(ApT 12)

However, even disregarding the verb-late clauses in $\mathrm{OE}$, we find that the grammars are very different. In our corpus of OF, we never find an argument moved in front of the finite verb when the subject is preverbal. This is not the case in OE. Based on this, we have claimed that only one element may move in front of the finite verb in OF, whereas at least two elements may be moved there in $\mathrm{OE}$. We believe the restriction found in $\mathrm{OF}$ is the reflection of a syntactic constraint that requires one and only one element to be moved across the finite verb. In $\mathrm{OE}$ no such syntactic constraint exists, and elements are moved in front of the finite verb in order to check information-structural features.

As we have previously examined clauses with preverbal subjects, we will now look at clauses in which the subject occurs after the finite verb. Considering the differences between the two languages in the clauses we have already analyzed, we want to know if similar differences may be observed when the subject occurs in postverbal position.

The outline of this paper is as follows: In section [2] we describe the method used and the key data. In section [3] we take a closer look at the distribution of the different kinds of subjects with respect to type (pronoun vs. DP), as well as with respect to other elements in the clause. In section [4] we attempt to give a syntactic account of the patterns we observe, and in section [5] we outline what effects may potentially be ascribed to information structure. Finally, in section [6] we pull the threads together and present the conclusion.

\section{[2] METHOD AND KEY DATA}

The study is based on prose texts. In the case of $\mathrm{OE}$, the data stem from five different texts: Bede's Ecclesiastical History of the English People (Bede, manuscripts first half of 10th cent.), Orosius (Or, manuscripts early 10th cent. and 11th cent.), Ælfric's Lives of Saints (ÆLS, manuscript early 11th cent.), Apollonius of Tyre (ApT, manuscript mid-11th cent.), and the Peterborough Chronicle (ChronE, manuscript first half of 12 th cent.). The total number of excerpted clauses is 1,496 declarative main clauses, out of which 589 clauses have the subject in postverbal position. The example references refer to the page number of the editions used. 
The Old French data are taken from two prose texts: Le roman de Tristan en prose (Tr, c. 1230) and La Mort Artu (MoA, c. 1240). The total number of declarative main clauses is 1,821 , out of which 338 have the subject in postverbal position. The example references refer to the paragraph (Tristan) and sentence ID in the ISWOC corpus (La Mort Artu).

The distribution of word order with respect to the internal order of subject and verb is presented in Table 1.

TABLE 1: The distribution of pre- and postverbal subjects in Old English and old French

\begin{tabular}{|l|rr|rr|}
\hline & \multicolumn{2}{|c|}{ Old English } & \multicolumn{2}{c|}{ Old French } \\
& no. & $\%$ & no. & $\%$ \\
\hline Preverbal subjects & 907 & 60.6 & 932 & 51.2 \\
Postverbal subjects & 589 & 39.4 & 338 & 18.6 \\
Null subjects & - & - & 551 & 30.3 \\
\hline Total & 1,496 & 100.0 & 1,821 & 100.1 \\
\hline
\end{tabular}

We see that postverbal subjects are less frequent than preverbal or null subjects. In OE, they constitute around $40 \%$ of our selection; in OF only around $18 \%$. The reason for this difference may be that OF allows null subjects, and these occur when an XP other than the subject precedes the finite verb (as initially observed by Foulet (1930)). In other words, the language user had the choice between omitting the subject altogether or expressing it in a postverbal position when something other than the subject preceded the finite verb. Our data show that omitting the pronominal subject was more common than expressing it. In (9) the subject has been omitted, and in (10) it is expressed. Both clauses have the adverb mieuz 'better' in clause-initial position (the conjunction car 'for' is not part of the clause structure). We will not consider null subjects in this paper.

(9) Mieuz vodroient rendre le treü que lor peres avoit rendu. better would give the tribute than their father had given 'They would rather give [them] the tribute that their father had given'

(Tr 292)

(10) car mieuz voudroit il estre toz jorz en servaige.

for better want he be all days in slavery

'for he would prefer to remain a slave all his days'

(Tr 289)

When we consider the clauses with postverbal subject, we get the word order distribution shown in Table 2 on the facing page. ' $X$ ' stands for 'any clause element other than the subject and the finite verb'. 
TABLE 2: The distribution of word order with postverbal subjects

\begin{tabular}{|l|r|r|r|r|}
\hline & \multicolumn{2}{|c|}{ Old English } & \multicolumn{2}{c|}{ Old French } \\
& no. & $\%$ & no. & $\%$ \\
\hline VS & 98 & 16.6 & 60 & 17.8 \\
VSX & 393 & 66.7 & 245 & 72.5 \\
VXS & 66 & 11.2 & 20 & 5.9 \\
VXSX & 32 & 5.4 & 13 & 3.8 \\
\hline Total & 589 & 99.9 & 338 & 100.0 \\
\hline
\end{tabular}

Table 2 shows that most of the sentences have material after the subject (VSX and VXSX) - around 70\% in both languages. We also see that in many cases, material may intervene between the finite verb and the subject (VXS and VXSX). What interests us is to know what kind of material may occur in this intermediate position and also if there is a difference between pronominal and full DP subjects (henceforth DP subjects).

\section{[3] SUBJECTS AND OTHER ELEMENTS IN THE CLAUSE}

We know that postverbal subjects may occupy different positions also in Germanic languages. In an overview, Haeberli (2000) shows how closely related languages, such as German and West Flemish on the one hand or Norwegian and Danish on the other, may behave differently with respect to the position of DP subjects. Whereas German and Norwegian permit adverbials between the finite verb and the postverbal DP subject - (11) and (13), West Flemish and Danish do not - (12) and (14). All examples from Haeberli (2000); translations added by us.

(11) Wahrscheinlich wird (später) Hans dieselbe Uhr kaufen probably will (later) Hans the-same watch buy 'Hans will probably buy the same watch later'

(German)

(12) Misschein goa (*loater) Jan tzelfste orloge kuopen probably go (later) Hans the-same watch buy 'Hans will probably buy the same watch later'

(West Flemish)

(13) Denne klokka hadde (seinere) min gamle far kjøpt this watch had (later) my old father bought 'My old father had later bought this watch'

(14) Dette ur vil (*senere) min far købe. this watch will (later) my father buy 'My father will buy this watch later' 
Adverbs intervening between the verb and the subject are, however, only possible with DP subjects. When the subject is pronominal, it must be adjacent to the finite verb when it occurs in postverbal position.

$$
\begin{aligned}
& \text { Wahrscheinlich wird (*später) er dieselbe Uhr kaufen } \\
& \text { probably will (later) he the-same watch buy } \\
& \text { 'He will probably buy the same watch later' }
\end{aligned}
$$

$$
\begin{aligned}
& \text { Denne klokka hadde (*seinere) han kjøpt } \\
& \text { this watch had (later) he bought } \\
& \text { 'He had later bought this watch' }
\end{aligned}
$$

It is important to note that this difference is not the result of cliticization. In the examples in (16), the pronouns are not clitics, even though it may be argued that the pronoun in Norwegian is weak in the sense of Cardinaletti \& Starke (1999). ${ }^{2}$

The difference between the two patterns may be explained by the subjects occupying two different positions in the structural hierarchy. In order to determine what positions these are in the case of $\mathrm{OE}$ and $\mathrm{OF}$, we will look at the distribution of pronominal and DP subjects with respect to non-finite verbs, adverbials, and other arguments. In doing so we will deviate from Haeberli (2000), who only considers adjuncts (adverbials in our terminology).

\section{[3.1] Pronominal subjects and full DP subjects}

In the analysis of our data, we distinguish between DP subjects, pronominal subjects and other. The group other comprises clausal subjects (only OE), and nonpersonal pronouns (such as demonstrative cil 'that one' in OF). ${ }^{3}$

When we look at Tables 3 and 4, which show how the different types of subjects are distributed with respect to the different word orders, we see that the distribution in OE and OF is remarkably similar. In both languages, the pronominal subject must follow the finite verb immediately. We may thus conclude that the pronominal subject may not be separated from the finite verb when it occurs postverbally. The same observation was made by Vance (1997) for OF.

We also see that DPs are preferred if the subject is in clause-final position, and that pronominal subjects occur in such a position less than $5 \%$ of the time. The DP subject may be separated from the finite verb in both languages.

[2] Colloquial Norwegian does, however, have pronominal clitics, which can be considered as simple clitics in the terminology of Zwicky (1977). These are ' $a$ 'she' and 'n 'he' and are as such distinguishable from the weak pronominal forms.

[3] In the OE data, seven clauses with an appositional subject (e.g. he, the king) have been omitted, as well as five clauses in which the pronominal subject is postmodified (typically relative clauses of the kind he who serves God). The four pronominal subjects in the VXSX pattern are all instances of mon 'one'. In the category 'other', all the subjects are clausal subjects in the OE data. 
TABLE 3: Subject types with the different word orders

\begin{tabular}{|l|rr|rr|rr|}
\hline & \multicolumn{6}{|c|}{ Old English } \\
\hline & \multicolumn{2}{|c}{ DP } & \multicolumn{2}{c|}{ pronoun } & \multicolumn{2}{c|}{ other } \\
& no. & $\%$ & no. & $\%$ & no. & $\%$ \\
\hline VS & 76 & 20.2 & 8 & 4.7 & 13 & 43.3 \\
VSX & 227 & 60.4 & 159 & 93.0 & 0 & 0.0 \\
VXS & 46 & 12.2 & 0 & 0 & 17 & 56.7 \\
VXSX & 27 & 7.2 & 4 & 2.3 & 0 & 0.0 \\
\hline Total & 376 & 100.0 & 171 & 100.0 & 30 & 100.0 \\
\hline
\end{tabular}

TABLE 4: Subject types with the different word orders

\begin{tabular}{|l|rr|rr|rr|}
\hline & \multicolumn{6}{|c|}{ Old French } \\
\hline & \multicolumn{2}{|c|}{ DP } & \multicolumn{2}{c|}{ pronoun } & \multicolumn{2}{c|}{ other } \\
& no. & $\%$ & no. & $\%$ & no. & $\%$ \\
\hline VS & 42 & 26.9 & 7 & 4.4 & 11 & 50.0 \\
VSX & 84 & 53.8 & 153 & 95.6 & 8 & 36.4 \\
VXS & 18 & 11.5 & 0 & 0.0 & 2 & 9.1 \\
VXSX & 12 & 7.7 & 0 & 0.0 & 1 & 4.5 \\
\hline Total & 156 & 99.9 & 160 & 100.0 & 22 & 100.0 \\
\hline
\end{tabular}

PRONOMINAL SUBJECT ADJACENT TO THE FINITE VERB

(17) Enfant, mar fustes vos onques né et engendré! child badly were you ever born and conceived 'Child, cursed be your conception and birth'

(18) pa wundrade he swiðe

then wondered he much

'then he wondered much'

(Bede 114)

DP SUBJECT SEPARATED FROM THE FINITE VERB

(19) Bien nos a fait Diex grant honor et grant misericorde well us has done God big honour and big grace 'God has shown us great honour and big grace'

(20) ba becom hyre on hand pæs halgan apostoles lar then came her on hand the holy apostle's doctrine 'then came into her hands the holy apostle's doctrine' 


\section{[3.2] Subjects and objects}

The next point to consider is the position of postverbal non-pronominal subjects with respect to objects in the text. As we have already established that pronominal subjects are almost always adjacent to the finite verb (see Table 3), we know that they will precede the non-finite verb, and they are thus not included here. In the case of OF, pronominal objects have been excluded as well, as these are always clitics on the verb. In OE, there are no pronominal clitics (Bech 2001), so pronominal objects have been included in Table 5.

TABLE 5: The distribution of DP objects and pronominal objects in relation to DP subjects

\begin{tabular}{|l|r|r|}
\hline & Old English & Old French \\
\hline DP subject - DP object & 44 & 12 \\
DP object - DP subject & 4 & 1 \\
DP subject - Pron. object & 5 & - \\
Pron. oSbject - DP subject & 14 & - \\
\hline
\end{tabular}

In OE, the DP subject almost always precedes the DP object (21).

(21) 7 berað pa Cwenas hyra scypu ofer land on ða meras and carry the Kvens their ships over land into the lakes 'and the Kvens carry their ships over land into the lakes'

In our data, the DP object precedes the subject in four sentences. In these cases, the subject is both HEAVY (i.e. modified) and NEW, hence the clause-late position. Consider examples (22) and (23).

(22) Swelce eac tocetecte pisse gedrefnisse storm Sæberhtes deað so also increased this.GEN confusion.GEN storm Sæberht's dead Eastseaxna cyninges

Eastsaxons.GEN king.GEN

'The death of Sæberht, king of the East Saxons, also increased the tempest of this confusion'

(Bede 112)

(23) Hofde ærest pisses gemetes rice Ælle Suðseaxna cyning had first this.gen measure.gen power Ælle Southsaxons.gen king 'Ælle, king of the South Saxons, was the first who had power of this measure'

(Bede 108)

In (22), the subject, Sceberhtes deað Eastseaxna cyninges 'the death of Sæberht, king of the East Saxons' is both NEW and HEAVY, hence it is placed after the object pisse gedrefnisse storm 'the tempest of this confusion', which is also HEAVY, but conveys 
GIVEN information. The same is the case in (23), where bisses gemetes rice'power of this measure' is GIVEN and HEAVY, whereas the subject Ælle Suðseaxna cyning 'Ælle, king of the South Saxons' is NEW and HEAVY.

As regards the ordering of DP subjects in relation to DP objects and pronominal objects in $\mathrm{OE}$, it is as expected that in most cases, pronominal objects precede DP subjects, since OE word order is subject to information-structural pressure. If the pronominal object follows the DP subject, it is either a deictic demonstrative, such as poet 'that' in (24), or the order pronominal object before DP subject might cause confusion, as in (25), where there is no case marking on Eugenia, and the form $h i$ can be a nominative or accusative. Thus, if the order had been Đa nam hi Eugenia on sundorsprcece, hi might easily be construed as the subject and Eugenia as the object, since subject-before-object is the most common order.

(24) एa gebafode se casere pæt ðam geræfan then granted the emperor that to-the governor 'Then the emperor granted that to the governor'

(ÆLS 40)

$$
\begin{aligned}
& \text { Đa nam Eugenia hi on sundorspræce } \\
& \text { then took Eugenia them in private-speech } \\
& \text { 'Then Eugenia took them apart in conversation' }
\end{aligned}
$$

In OF the subject almost always precedes the DP object. Some of these objects are modified, so that weight may come into play, but others are plain DPs, as in (26). The only exception in our data is the example in (27), where the object Tristan precedes the subject la longe maladie qu'il avoit eüe 'the long illness that he had suffered'. In this case the word order has most likely been dictated by weight.

(26) Ensi chastie Gorvenal son menistre

this-way warned Gorvenal his master

'This way Gorvenal warned his master'

(Tr 254)

(27) car mout avoit empirié Tristan la longe maladie qu' il avoit eüe. for much had worsened Tristan the long illness that he had had 'For the long illness he had suffered had made Tristan much worse' (Tr 317)

\section{[3.3] Postverbal subjects and adverbs}

The position of adverbs may provide us with information about the exact position of the subject.

In OE, negation is clitizised on the verb, unlike in OF, where it may occur before and after the subject. Therefore, in the case of OF, we have counted the negation as an X-element in our tables. We have already shown that personal pronouns are not separated from the finite verb, and this is also the case when the verb is negated. This was first observed for OF by Vance (1997), and our data confirm this. 
The pronominal subject always precedes negation (28), whereas the DP subject follows it (29).

(28) Or nel feroie je pas! now NEG-it do I NEG 'Now I will not do it'

(Tr 279)

(29) icele nuit $\mathrm{n}$ ala pas mes sire gauvains a cort this night NEG went NEG my sir Gauvain to court 'This night sir Gauvain did not go to court'

(MoA 93427)

In $\mathrm{OE}$ as well, the pronominal subject follows the finite verb immediately (see Table 3), as in (30).

(30) pa he onweg adrifen wæs, cwom he to Cent when he away driven was came he to Kent 'when he was driven away, he came to Kent'

(Bede 118)

Because of this consistent behaviour of pronominal subjects, we have excluded them from this section. Here, we will only look at DP subjects and their position with respect to adverbs. What interests us it to examine which adverbs may precede the subject and which elements may follow it.

In OF, the adverbs that precede the DP subject are typically short adverbs. In addition to the negation pas we find lors 'then', ja 'already', and tant 'so much'.

$$
\begin{aligned}
& \text { et estoit ja li tornoiemenz si pleniers qu[e] ... } \\
& \text { and was already the tournament so full that } \\
& \text { 'and there were already so many people at the tournament that ...' }
\end{aligned}
$$

(MoA 93237)

There is also one instance of two adverbs (lors 'then' and the PP par devant 'in front of') preceding the DP subject, but in that case the subject is very heavy, containing a relative subclause.

(32) Si passa lors par devant li uns nens qui mout savoit des choses SI passed then for front the one dwarf that much knew of things qui estoient a venir that were to come 'Then, right in front of them, came the dwarf who knew a lot about the things to come'

(Tr 259)

Adverbials that follow the subject are typically longer, such as DPs (33) and modified adverbs (34). 
(33) En cele chambre fu Tristanz dis jorz entiers in this room was Tristan ten days whole 'Tristan spent then full days in this room'

(34) cele nuit dormi mes sire gauvains moult petit this night slept my sir Gauvain much little 'This night sir Gauvain slept very little'

(MoA 93540)

In OE there are several examples of longer adverbs between the finite verb and the DP subject. As we saw for OF in (32), the adverbs may also cluster in this position in $\mathrm{OE}$, as in (35).

(35) 7 hym woes ða twegen dagas on ðæt bæcbord pa igland pe in and him was then two days on the port the islands that to Denemearce hyrað

Denmark belong 'and then, for two days he had the islands that belong to Denmark on the port side'

(Or 16)

We also find DP subjects following short adverbs, such as a 'always' in (36).

$$
\begin{aligned}
& \text { him woes a widsæ on pæt bæcbord } \\
& \text { him was always widesea on the port } \\
& \text { 'there was always a wide sea on the port side' }
\end{aligned}
$$

According to Cinque (1999), adverbs are the specifiers of functional heads, and their order is hierarchically organized cross-linguistically (38). This order is taken to be a universal.

(37) généralement 'generally', habituellement 'normally' > pas 'not' > déjà 'already', (pas) encore '(not) yet' > plus 'more', encore 'again' > toujours 'always', jamais 'never' > complètement 'completely', partiellement 'partially' $>$ tout 'all', rien 'nothing' > bien 'well', mal 'badly'

Even though Cinque does not map the adverbial hierarchy onto the existing domains (CP, IP and VP), it is clear that an adverb such as bien 'well' sits very low in the structure. In the literature, adverbs corresponding to well are taken to mark the border between the IP-field and the vP-field. In other words, it would be a clear indication that a DP subject has not evacuated the vP if it follows adverbs such as bien 'well'.

The adverbs we have discussed so far (such as OE a 'always', OF ja 'already') belong to the IP-field of Cinque's hierarchy. We do, however, find adverbs that indicate that the DP subject has not moved into the IP-field. In (38), the DP sub- 
ject Tristanz follows the adverb bien, which belongs to the lowest position in the adverbial hierarchy, according to Cinque.

$$
\begin{aligned}
& \text { et tot ce savoit bien Tristanz meïsme } \\
& \text { and all that knew well Tristan himself } \\
& \text { 'and Tristan himself knew that well' }
\end{aligned}
$$

Vance (1997) suggests that the postverbal subject in OF may occur either under SpecTP or SpecVP ${ }^{4}$, but our data do not indicate that the DP subject has moved out of vP at all.

In OE, we saw in (36) that the adverb a 'always' precedes the subject. 'Always' is not one of the adverbs that are thought to mark the border between the IP and the vP, as it sits in the middle of the hierarchy. As such we may not categorically say that the postverbal subject has not moved out of the VP in OE, but we may say that it has not moved to the upper part of the IP-field.

\section{[3.4] Subjects and complex verb phrases}

It is not only adverbs and objects that may separate the DP subject from the finite verb. In complex verb phrases, the subject may also follow the non-finite verb. The distribution of DP subjects in relation to non-finite verbs is presented in Table $6 . .^{5}$

TABLE 6: The position of the DP subject in relation to the non-finite verb

\begin{tabular}{|l|r|r|}
\hline NF $=$ non-finite & $\begin{array}{r}\text { Old English } \\
\text { DP subject }\end{array}$ & $\begin{array}{r}\text { Old French } \\
\text { DP subject }\end{array}$ \\
\hline V-S-NF & 49 & 12 \\
V-NF-S & 18 & 15 \\
\hline
\end{tabular}

Non-finite verbs and DP subjects in Old French

When we look at different verb types and constructions as presented in Table 7, we see that the DP subject is most likely to occur after the non-finite verb with most kinds of verbs and constructions. Note that it is possible to combine e.g. a transitive verb with a modal auxiliary. In such cases, we list the verb under modal rather than transitive.

[4] In Vance's approach there is no vP, only VP.

[5] For OE, Table 6 includes clauses with a passive participle and clauses with modal + infinitive, as well as one example with habban 'have' + a participle. Constructions with a present participle have been left out, since their status as verbal in OE is unclear (Traugott 1992, 190). Note that for both languages, other possible sentence elements are not included in the table; the table only shows whether the subject occurs before or after the non-finite verb, and not other elements that may occur in between these main elements. 
TABLE 7: Type of verb with respect to postverbal DP subjects in OF. NF=non-finite verb

\begin{tabular}{|l|r|r|}
\hline type of construction & V-S-NF & V-NF-S \\
\hline transitive & 2 & 6 \\
unaccusative & 1 & 3 \\
copula & 1 & 0 \\
passive & 2 & 5 \\
modal & 2 & 1 \\
factive & 4 & 0 \\
\hline total & 12 & 15 \\
\hline
\end{tabular}

The only type of construction where the subject always precedes the nonfinite verb, is the factive, where an infinitive follows the factive verb faire 'make' (39).

(39) A l' endemain aprés ore de prime fist li rois venir sa fille on the following-day after hour of first made the king come his girl devant li en une soe chambre before him in one his chamber 'The following day, after the first hour, the king summoned before him the girl in one of his private chambers'

(Tr 382)

We see that the subject often follows the non-finite verb with unaccusatives, passives, and ordinary transitives. As we know that the subject is generated in object position in unaccusative and passive constructions (Perlmutter 1978; Helland 2001; Legendre \& Sorace 2003), it is not unexpected that these subjects follow the participle. This word order would simply reflect that the subject sits in its base position (40). We note, however, that this is not an obligatory position for the subject (41).

(40) Si estoient la venu li baron de maint reaume SI were there come the noblemen of many kingdoms 'The noblemen from many kingdoms had come there'

(41) et porce qu il ne pueent mie assembler a leur volente quant and for that what they NEG can NEG assemble at their will when vos i estes, est Lancelos remes, qu il $\mathrm{n}$ ira pas au you there are is Lancelot remained for he NEG goes NEG to-the tornoiement de wincestre tournament of Wincester 
'And because they cannot get together when they want to when you are there, Lancelot stayed behind as he is not going to the tournament of Winchester'

(MoA 93025)

More surprisingly, we observe that also with transitive verbs, the subject normally follows the participle. This cannot be ascribed to weight only, as in (27). In other cases, the subject may be fairly short (42).

(42) et por la proesce de li l' avoit retenu li Morholz en sa and for the courage of him him had kept the Morholt in his compaignie company 'and Morholt had kept him in his company because of his courage'

(Tr 287)

A final point to make is the behaviour of factives in OF (see example (26)). Unlike the other constructions, the subject of the factive is not generated in the same vP as the non-finite verb. In factive constructions, the subject of the factive verb is not the subject of the non-finite verb. We take it that the subject and the infinitive have not been merged in the same projection, and that the factive infinitive is more deeply embedded than the infinitive in modal constructions. This may explain why subjects may not follow the infinitive.

\section{Non-finite verbs and DP subjects in Old English}

In our $\mathrm{OE}$ data, there is only one example of a complex verb phrase corresponding to the modern English perfect aspect. The great majority of the constructions are passive constructions and modal constructions. What we see is essentially the same pattern as in OF: In passive constructions, the subject may precede or follow the non-finite verb (43).

(43) pær wearð Marsepia sio cwen ofslagen there was Marsepia the queen killed 'there Queen Marsepia was killed'

(44) and weran gegeorcode pa reðan wyta and were prepared the cruel tortures 'and the cruel tortures were prepared'

There is only one example of a DP subject and a compound form with an unaccusative verb. In this case, the DP subject is postverbal (45). 
(45) 7 On pam fare wurdon adr[u]ncene pæs cynges twegen sunan and on that journey were drowned the king's two sons Willelm 7 Ricard William and Richard 'and on that journey the king's two sons William and Richard drowned'

(ChronE 40)

Constructions in which the non-finite verb is an infinitive have the subject in front of the non-finite verb (46) in the great majority of cases, but see (47) for an example in which the subject follows the infinitive. This is the same tendency we observed for OF.

(46) ba nolde basilla . brydguman geceosan

then not-would Basilla . bridegroom choose

'then Basilla would not choose a bridegroom'

(ÆLS 46)

(47) 7 sceall beon se læsta dæl nyhst pæm tune ðe se deada man on and shall be the least part next to-the town the the dead man in lið

lies

'and the least part shall be next to the town in which the dead man lies'

(Or 17)

\section{[3.5] Summing up}

We see that in clauses with a postverbal subject, pronominal subjects follow the finite verb immediately in both $\mathrm{OE}$ and OF. As regards DP subjects, we have seen that heaviness plays an important role in subject placement. If the subject is heavy, for example if it is modified, it is most likely to appear in final clause position. If we disregard the heavy subjects, we may observe the following

- the DP subject precedes the DP object

- the DP subject can both precede and follow the non-finite verb

- the DP subject follows certain adverbials and precedes others

In section [4] we will seek a model that can account for these data.

\section{[4] SYNTAX}

The position of subjects has been discussed for both OE and OF. A strong tradition for OE suggests that there are two subject positions in OE: A higher position for pronouns and a lower for DPs (Pintzuk 1993, 1999; Pintzuk \& Haeberli 2008). Haeberli $(2000,2002)$ identifies the higher subject position as SpecAgrP, and the 
lower as SpecTP. In clauses that are not verb-final or verb-late, the finite verb will normally move to Agr ${ }^{\circ}$. This implies that a pronominal subject will be preverbal unless the finite verb moves to the C-domain. A DP subject, on the other hand, will be postverbal in clauses that contain a finite verb in a high position. Occurrences of preverbal DP subjects are analyzed as instances of topicalization, in which the DP subject occupies SpecCP, but the verb has not moved into the C-domain. ${ }^{6}$ According to the tradition following Pintzuk (1993), the finite verb only moves to $C^{\circ}$ in wh-clauses, verb-initial clauses, and following certain adverbs, such as $b a$ 'then' (48). $\mathrm{S}_{P}$ means pronominal subject; $\mathrm{S}_{D P}$ nominal subject.

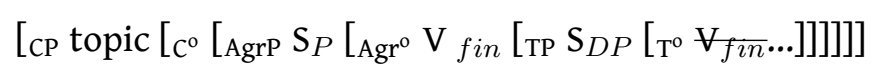

The derivation of $\mathrm{OE}$ is not straightforward, as it is common to presume that the language has a right-branching VP (see inter alii Pintzuk (1993) and subsequent literature). It is possible to use a Kaynian approach (Kayne 1994) and propose that the cases of OV in OE are derived by different movement operations, and that the whole language structure is left-branching. In either case, we must assume that the subject is merged in vP and that it moves to its surface position.

For OF, Vance (1997) suggests that the postverbal pronominal subject cliticizes on the finite verb, which moves to $C^{\circ}$. The postverbal DP subject may either occupy SpecTP or SpecVP. Note that in Vance's model, the finite verb only moves to $\mathrm{C}^{\circ}$ when an element other than the subject precedes it. Vance's analysis for postverbal pronominal subjects is presented in (49); and the analysis for postverbal DP subjects is presented in (50). Vance distinguishes between AgrP and TP within the IP-field. If the subject is a DP, both are projected, and the DP subject occupies the lower projection. With pronominal subjects, IP is not split, and the subject sits under SpecIP. According to Vance, SpecAgrP is an A' position and is only available to subjects in preverbal position.

$$
\begin{aligned}
& {\left[\mathrm{CP} X P\left[\mathrm{c}^{\circ} \mathrm{V}_{f i n}+\mathrm{S}_{P}\left[{ }_{I P} \mathrm{~S}_{P}\left[\mathrm{I}^{\circ} \mathrm{V}_{f i n}\left[\mathrm{vP} \mathrm{S}_{P}\left[\mathrm{~V}^{\circ} \mathrm{V}_{f i n}\right]\right]\right]\right]\right]\right]} \\
& {\left[\mathrm{CP} \mathrm{XP}\left[\mathrm{c}^{\circ} \mathrm{V}_{f i n}\left[\mathrm{TTP}_{D P}\left[\mathrm{~T}^{\mathrm{o}} \mathrm{V}_{f i n}\left[\mathrm{vP} \mathrm{S}_{D P}\left[\mathrm{v}^{\circ} \mathrm{V}_{f i n}\right]\right]\right]\right]\right]\right.}
\end{aligned}
$$

We see that the models have identical points. First, we can conclude that both $\mathrm{OE}$ and OF pattern with languages such as Norwegian and German in that pronominal subjects and DP subjects appear in different positions, cf (11). The pronoun sits higher than the DP subject. In what follows, we will focus on the DP subject.

[6] Note that this is not the only analysis in the literature. See Walkden (2012, To appear) for an approach where the verb obligatorily moves to the left periphery. However, Walkden does not discuss subject positions, so we do not consider his analysis in this presentation. 


\section{[4.1] The DP subject in the $v P$}

The fact that a postverbal DP subject may occur after a non-finite verb is somewhat troublesome. Even if the subject has not moved out of vP, we expect the subject of a transitive or ergative verb in a left-branching structure, to be merged under SpecvP, thus preceding the participle (Kratzer 1996). The verb will be merged in $\mathrm{V}^{\mathrm{o}}$ and then move to $\mathrm{v}^{\mathrm{o}}$. If the verb under $\mathrm{v}^{\mathrm{o}}$ is non-finite, an auxiliary will be merged in some designated head in the IP-field (presumably Aux ${ }^{\circ}$ ). If the verb is finite, it will move from $v^{0}$ to its final landing site in the IP- or CP-field (depending on language-specific configurations). This gives us the outline of the VP as presented in Figure 1.

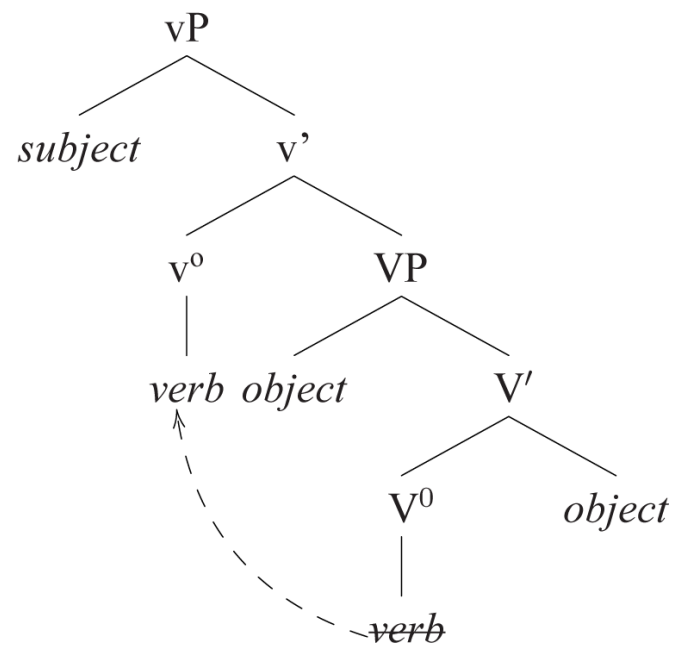

FIGURE 1: vP and VP

In the case of unaccusative verbs and passive constructions, the subject is merged in object position, in other words in SpecVP. If we hypothesize that the verb must always move to $\mathrm{v}^{\mathrm{o}}$, we immediately see the reason for postverbal DP subjects in unaccusative and passive structures (see also Radford $(2004,351)$ ). The structure is presented in Figure 2 on the following page.

In $\mathrm{OE}$, there is no distinct syntactic pattern as regards the position of the DP subject with respect to the participle in passive constructions. In the case of OF, we see that with unaccusative verbs and passive constructions, the subject normally remains in the position in which it has been merged. We do, however, have one example in which the subject of an unaccusative verb precedes the non-finite verb. In addition, with six out of the eight transitive verbs, the participle precedes the DP subject. As we saw in Figure 1, this is not expected, as the subject is 


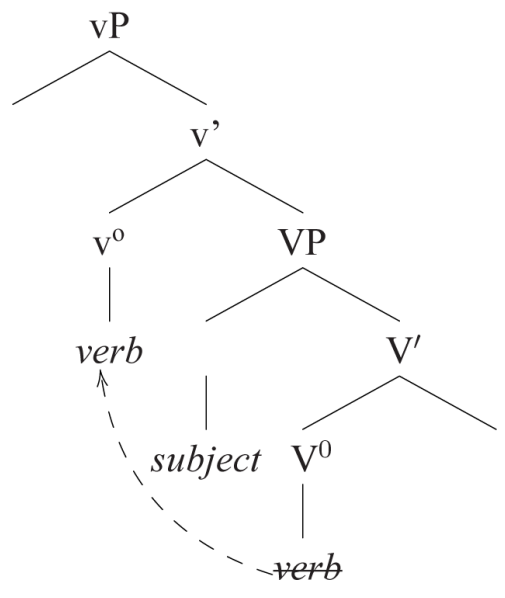

FIGURE 2: VP and VP with unaccusative verbs and in passive constructions

merged to the left of $\mathrm{v}^{\mathrm{o}}$. It follows from this that in both OE and OF, the passive subject must have moved after it has been merged.

Our model is in other words not able to account for the data found in our corpus. On the one hand, we have made the assumption that the DP subject has not evacuated the vP. On the other hand, we see that the word order participle-DP subject is not possible within a standard model of the vP.

In order to solve this problem, we will use insights from Poletto $(2006,2011)$ who has investigated similar constructions in Old Italian. She proposes that in Old Italian, there is a left periphery in the vP, which behaves much in the same way as the higher left periphery. In other words: If there is obligatory verb movement to the higher left periphery, then there is obligatory verb movement to the lower left periphery. In addition, there are specifier positions in the lower left periphery that may host different phrases. In (51), the object il passo 'the step' occurs in front of the past participle pigliato 'taken', a position that indicates movement of the object across the participle. Poletto suggests that il passo occupies a specifier position to the left of $\mathrm{vP}$, in what she describes as the left periphery of the $\mathrm{vP}$. This projection is consequently a part of the vP-phase and has not moved into the IPfield. In what follows we will refer to this as the lower left periphery or the expanded $v P$.

(51) i nimici avessero già il passo pigliato the enemies had already the step taken 'The enemies had already taken the step'

(Bono Giamboni, Orosio, p 88, r. 15, cit. Poletto (2006)) 
Similar constructions to the ones discussed by Poletto may be found in OF, as pointed out by Salvesen (2011). In (52) the indirect object la royne 'the queen' occurs in front of the infinitive conter 'tell'.

Uns més le va tantost la royne conter a messenger it goes immediately the queen tell 'A messenger will immediately tell it to the queen'

(Berthe, 3377) $)^{7}$

Consequently, if there is an additional left periphery in the vP, we must assume at least one specifier position and one head to the left of vP, but not as high as the IP-field. For lack of a better denomination, we will call this projection YP. The structure is presented in Figure 3. Poletto's analysis implies obligatory movement of the verb to $\mathrm{Y}^{\circ}$, and then possible $\mathrm{A}^{\prime}$ movement to SpecYP. Everything within the marked square belongs to the expanded vP-field.

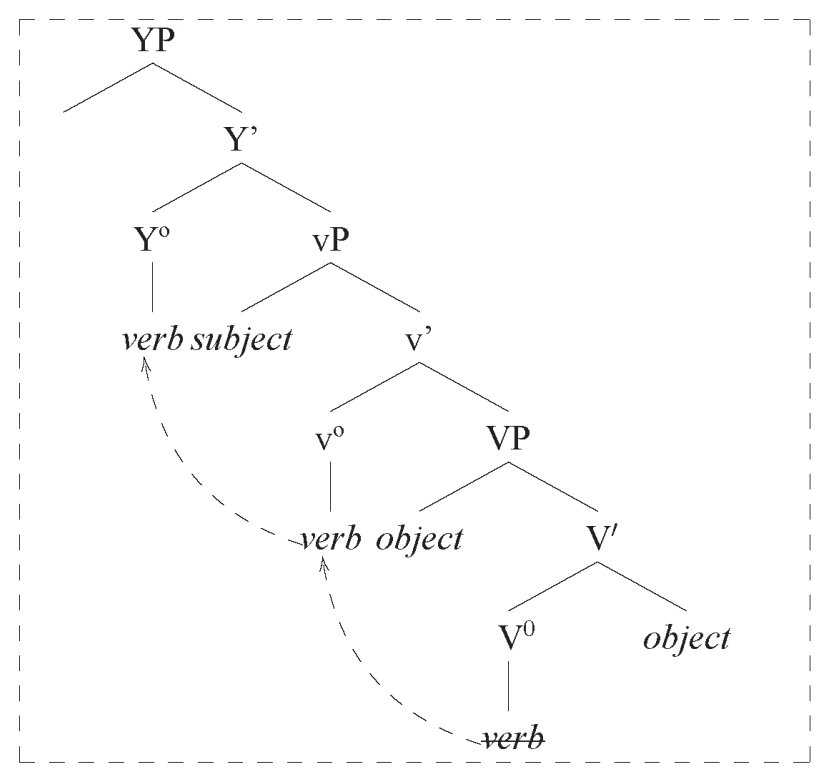

FIGURE 3: The left periphery of the vP

If we adopt Poletto's analysis, we see how transitive constructions in OF may have the DP subject after the non-finite verb: The non-finite verb has moved to $\mathrm{Y}^{\mathrm{o}}$, and the subject remains in SpecvP. ${ }^{8}$ Consequently, in the examples where the

[7] Adenet le Roi: Berthe aus grans piés (written 1269-1285), retrieved from Corpus de la Littérature Médiévale.

[8] The OI example has a compound verb tense, whereas the OF example is periphrastic with the verb aler 'go'. They are, however, comparable, as they are both monoclausal structures with a non-finite verb. In the OF example, the object clitic le 'it' is proclitic to the auxiliary. As clitics may not move across clause boundaries, we may safely assume that the OF example is monoclausal. 
DP subject precedes the non-finite verb, the subject has moved by A'-movement to SpecYP. We have already seen that this kind of A'-movement exists independently in OF (see also Myking (2012)).

The same model works well for the OE data, especially for the cases where a passive subject precedes the non-finite verb: We will assume that the subject has moved past the participle to SpecYP (as SpecvP is an A-position, this is not a possible landing site).

Poletto (2011) suggests that the lower left periphery has several A' landing sites, just like the exploded CP-field. She quotes several examples in which the non-finite verb is preceded by two complements or adverbs. Interestingly, we find a similar example in the OE data. In (53), both the subject seo ceaster 'the city' and the predicative Antiochia precede the participle geciged 'called'. We take it that the subject and the predicative realize different specifier positions in the lower left periphery. In other words, there is not only a YP, but presumably also a ZP.

æfter pæs cyninges naman wces seo ceaster Antiochia geciged after the king's name was the city Antiochia called 'after this king's name the city was called Antioch'

To sum up: We make the claim that the postverbal DP subject never leaves the $\mathrm{vP}$ in OF or OE. The implication of this analysis is that Case checking is done by Agree, and not by Move.

\section{[5] INFORMATION STRUCTURE}

We have claimed that postverbal DP subjects in verbal complexes with non-finite verbs do not leave the expanded vP, neither in OE nor in OF, and we have also seen that there is variability with respect to the position of the DP subject: It can precede or follow the participle. In order to solve this problem, we propose that the vP may contain a 'low left periphery' (see Section [4]). The question is what motivates the low left periphery projection(s), and the movement or lack of movement of the subject. Myking $(2012,91)$ proposes that in OF, the scrambling position in the vP-field attracts arguments, especially if they contain GIVEN information. Our proposal is that information-structural factors, or weight factors, or both, come into play, and that there is a difference between $\mathrm{OE}$ and $\mathrm{OF}$ in this respect. In $\mathrm{OE}$, both factors apply, whereas in OF, it is mostly weight that is relevant.

The general presupposition is that GIVEN and LIGHT elements resist final position, whereas NEW and HEAVY elements tend to occur in a low position (principle of end focus and end weight, see e.g. Firbas (1992); Quirk et al. (1985)). So if the subject is GIVEN, it has to move up to SpecYP to check information-structural fea- 
tures there, in the same way that subjects move to SpecCP to check informationstructural features. If the subject is NEW or HEAVY, it stays in the lowest projection.

A comparison of $\mathrm{OE}$ and $\mathrm{OF}$ shows that this tendency is stronger for $\mathrm{OE}$ than for OF. In OE, the lowest subject is quite consistently NEW, and also often HEAVY, except in rare cases where other factors to do with sentence organization intervene. DP subjects that precede the participle usually convey GIVEN information. In OF, a GIVEN or INFERABLE subject can occur in the lowest position if it is HEAVY, or if other considerations to do with sentence structure necessitate it. Let us consider some examples from OE first. In (54), the GIVEN subject seo ceaster 'the city' precedes the participle, whereas in (55), the NEW subject sum iung man 'a young man' follows the participle. These clauses thus adhere to the common pattern.

(54) æfter pæs cyninges naman woes seo ceaster Antiochia geciged after the king's name was the city Antiochia called 'after this king's name the city was called Antioch'

(55) ða woes Apollonius gehaten sum iung man then was Apollonius called a young man 'then there was a young man called Apollonius'

Example (56) shows a subject in post-participle position that is strictly speaking GIVEN, since the referents have been mentioned before in the text. However, they are not mentioned in the immediately preceding context, and not in the same noun phrase. In (56), the referents come together in the same noun phrase, which consists of coordinated elements, and is therefore HEAVY.

(56) pa wurdon gefullode . philippus . and claudia . and heora twegen suna then were filled. Philip . and Clauda . and their two sons . mid soðum geleafan

. with true faith

'then Philip, Claudia, and their two sons were filled with true faith'

(ÆLS 40)

In (57), a NEW subject, an wyrt 'a herb' precedes the participle, which is unexpected. However, here the verb phrase constitutes a 'frame' around the information provided by the two adverbials and the subject.

Ac Alexandre wearð on ðære ilcan niht an swefne an wyrt oðewed But Alexander.DAT was in the same night in sleep a herb shown 'But in the same night a herb was shown to Alexander in a dream' 
Other configurations are less desirable, for example Alexandre wearð oðewed on Jcere ilcan niht an swefne an wyrt, which puts the subject at some distance from the lexical verb, or Alexandre wearð on ðcere ilcan niht oðewed an swefne an wyrt, which separates the two related adverbial prepositional phrases. A possible constituent order would be Alexandre wearð on ðxere ilcan niht an swefne oðewed an wyrt, which would place the NEw subject last, but it would also mean that the subject would be placed outside the frame of the verb phrase, in which the author of the original version has safely ensconced it, together with the adverbials. There is thus a cluster of non-verbal elements in the sentence brace.

In $\mathrm{OF}$, the picture is somewhat less orderly than in $\mathrm{OE}$, which is not unexpected, considering that OF seems to be less susceptible to the workings of information structure than OE is (Bech \& Salvesen 2014). As regards DP subjects that occur in front of the participle, they are invariably GIVEN or INFERABLE. The DP subjects that occur after the participle are often NEw, such as maint chevalier 'many knights' in (58), or NEW and HEAVY, as uns chevalier a qui ge voudroie resembler 'a knight whom I would like to resemble' in (59), but weight also seems to play an independent role, as in (60), where the subject la marrastre de Tristan 'the stepmother of Tristan' is GIVEN and HEAVY. In addition, a GIVEN subject may follow the participle if other factors to do with sentence structure dictate it. In (61), for example, the GIVEN subject may have been placed after the participle because that is the best position in relation to the adverbials, among others the adverbial phrase hui en cest jour 'this very day'.

(58) car cel jor l' orent veu maint chevalier a l' assemblee for that day him had seen many knights at the assembly 'for that day many knights had seen him at the assembly'

(MoA 93348)

(59) si l' a veincu uns chevaliers a qui ge voudroie resembler SI him has defeated a knight to whom I would resemble 'a knight whom I would like to resemble has defeated him' (MoA 93434)

(60) En tel maniere fu destorné la marrastre de Tristan de morir in such way was turned-away the stepmother of Tristan of die 'In this way Tristan's stepmother was saved from death'

(61) la soe grace par la proesce de Tristan est hui delivree en cest jor the his grace by the virtue of Tristan is today freed in this day Cornoaille de cuvertaige

Cornwall of vassalage

'by His [God's] grace by the virtue of Tristan, Cornwall was freed of vassalage'

(Tr 304) 
However, OF also has instances of seemingly free variation. Consider (62) and (63).

(62) Et por la petitesce de li, et porce que nens estoit, l' avoit and for the smallness of him and for that what dwarf was him had ses peres chacié d' entor li his father chased from around him 'Because of his small size and because he was a dwarf, his father had chased him away'

(Tr 259)

(63) et por la proesce de li l' avoit retenu li Morholz en sa and for the courage of him him had kept the Morholt in his compaignie company 'and Morholt had kept him in his company because of his courage'

(Tr 287)

In (62), the GIVEN subject is ses peres 'his father', and it precedes the participle chacié 'chased', whereas in (63), the GIVEN subject li Morholz follows the participle retenu 'kept'. These clauses are otherwise very similar in content and structure.

$\mathrm{OE}$ as well has instances of what seems like free variation. In the two very similar sentences in (64) and (65), the subject precedes the verb in the former, and follows the verb in the latter. The subject is GIVEN in both cases. ${ }^{9}$

(64) On pisum geare se cyng Willelm heold his hired to Cristesmessan on in this year the king William held his court to Christmas at Wæstmynstre

Westminster

'In this year, king William held his court at Christmas at Westminster'

(ChronE 18)

(65) On pison geare heold se cyng Henri his hyred to Natiuiteð on in this year held the king Henri his court at Nativity at Windlesoran

Windsor

'In this year, King Henry held his court at Nativity at Windsor'

(ChronE 36)

It seems that in in cases like this, neither syntactic models nor information structure models are able to account for the constituent order. We may thus have to accept that in the early stages of these languages, in which word order was freer than it is today, such free variation will occasionally occur.

[9] Note that these are instances of main clauses with simple verb phrases, and thus not of the kind discussed above; they were included to show the variation that may occur in OE. 


\section{[6] CONCLUSION}

Whereas our previous study of preverbal subjects showed that there are considerable syntactic differences between Old English and Old French, the syntax of postverbal subjects seems to be similar in the two languages. We have seen that in both languages, the pronominal subject is adjacent to the finite verb. As for postverbal DP subjects, we have suggested that they do not move out of the vP and that they check their case by Agree, not Move. We have proposed an identical model of the vP for both languages, in which there is a 'lower left periphery' to which elements may scramble in the vP.

As regards information structure, both languages are sensitive to weight. A heavy subject will more easily sit low in the structure than a light one. However, when it comes to the information value of $\mathrm{OE}$ and $\mathrm{OF}$ clause elements, a different pattern arises: Whereas information value seems to play a limited role in OF, it is an important factor in the word ordering of OE. In clauses with a complex verb phrase, a DP subject that precedes a non-finite verb is either GIVEN or INFERABLE, whereas a DP subject that follows the non-finite verb is normally NEW or NEW in combination with HEAVY. In OF, DP subjects that precede the non-finite verbs are GIVEN, but a GIVEN subject may occur after the non-finite verb if it is also HEAVY, or if other factors to do with sentence organization intervene. It should also be noted that in both languages, instances of seemingly free word order variation can be found.

There is, in other words, a fundamental difference between $\mathrm{OE}$ and OF when it comes to the role of information structure in the ordering of elements. Although we may argue that the underlying syntactic model is the same, OE exploits the possibilities that lie in the structure if information structure dictates it. OF, on the other hand, exploits the syntactic positions without being unduly restricted by information structure. When we examined preverbal subjects in $\mathrm{OE}$ and $\mathrm{OF}$, we suggested that preverbal word order in $\mathrm{OE}$ is essentially driven by information structure, whereas it is driven by syntax in OF. We see that this fundamental difference is reflected in the ordering of postverbal subjects as well.

\section{ACKNOWLEDGEMENTS}

We would like to thank two anonymous reviewers for helpful comments to this paper.

PRIMARY SOURCES

ÆLS Skeat, Walter W. (ed). 1881--1885. Ælfric's Lives of Saints, vol. I, i \& ii. EETS o.s. 76, 82. London: Trübner \& Co.

ApT Thorpe, Benjamin (ed). 1834. The Anglo-Saxon Version of the Story of Apollonius of Tyre. London: John and Arthur Arch. 
Bede Miller, Thomas (ed). 1890. The Old English Version of Bede's Ecclesiastical History of the English People. EETS o.s. 95, 96. London: Trübner \& Co.

ChronE Clark, Cecily (ed). 1958. The Peterborough Chronicle 1070-1154. London: Oxford University Press.

MoA La Mort Artu: data extracted from the ISWOC corpus (under construction). http://foni.uio. no:3000

Or Bately, Janet (ed). 1980. The Old English Orosius. EETS s.s. 6. London: Oxford University Press.

Tr Le roman de Tristan en prose, in the database Corpus de la Littérature Médiévale. http://www.classiques-garnier.com/numerique

REFERENCES

Adams, Marianne. 1987. From Old French to the theory of pro-drop. Natural Language and Linguistic Theory 5. 1-32.

Adams, Marianne. 1989. Verb second effects in Medieval French. In Carl Kirschner \& Janet Ann DeCesaris (eds.), Studies in Romance Linguistics: Selected Papers from the Seventeenth Linguistic Symposium on Romance Languages, 1-33. Amsterdam: John Benjamins.

Bech, Kristin. 2001. Word Order Patterns in Old and Middle English : A Syntactic and Pragmatic Study. Bergen: University of Bergen dissertation. https://bora.uib.no/handle/1956/3850.

Bech, Kristin \& Christine Meklenborg Salvesen. 2014. Preverbal word order in Old English and Old French. In Kristin Bech \& Kristine Gunn Eide (eds.), Information Structure and Syntactic Change in Germanic and Romance languages, Amsterdam: John Benjamins.

Cardinaletti, Anna \& Michal Starke. 1999. The typology of structural deficiency: A case study of the three classes of pronouns. In Henk van Riemsdijk (ed.), Clitics in the Languages of Europe, 145-233. Berlin: Mouton de Gruyter.

Cinque, Guglielmo. 1999. Adverbs and Functional Heads: A Cross-Linguistic Perspective. New York: Oxford University Press.

Firbas, Jan. 1992. Functional Sentence Perspective in Written and Spoken Communication. Cambridge: Cambridge University Press.

Foulet, Lucien. 1930. Petite syntaxe de l'ancien français. Paris: Champion. 
Haeberli, Eric. 2000. Adjuncts and the syntax of subjects in Old and Middle English. In Susan Pintzuk, George Tsoulas \& Anthony Warner (eds.), Diachronic Syntax: Models and Mechanisms, 109-131. Oxford: Oxford University Press.

Haeberli, Eric. 2002. Inflectional morphology and the loss of V2 in English. In David Lightfoot (ed.), Syntactic Effects of Morphological Change, 88-106. Oxford: Oxford University Press.

Helland, Hans Petter. 2001. Le participe passé et l'hypothèse inaccusative. In Langage et référence, 255-264. Uppsala: Acta Universitatis Upsaliensis.

Kayne, Richard S. 1994. The Antisymmetry of Syntax. Cambridge, Mass.: MIT Press.

Kratzer, Angelika. 1996. Severing the external argument from its verb. In Johan Rooryck \& Laurie Ann Zaring (eds.), Phrase Structure and the Lexicon, 109-138. Dordrecht: Kluwer.

Labelle, Marie. 2006. Clausal architecture in Early Old French. Lingua 117. 289-316.

Legendre, Géraldine \& Antonella Sorace. 2003. Auxiliaires et intransitivité en français et dans les langues romanes. In Danièle Godard (ed.), Les langues romanes. Problèmes de la phrase simple, 185-233. Paris: CNRS éditions.

Lightfoot, David. 1979. Principles of Diachronic Syntax. Cambridge: Cambridge University Press.

Lightfoot, David. 1999. The Development of Language: Acquisition, Change, and Evolution. Malden, Mass.: Blackwell.

Myking, Synnøve Midtbø. 2012. Le groupe prépositionnel en ancien et moyen français. University of Oslo MA thesis.

Perlmutter, David M. 1978. Impersonal passives and the unaccusative hypothesis. Proceedings of the Annual Meeting of the Berkeley Linguistics Society 4. 157-190.

Pintzuk, Susan. 1993. Verb-seconding in Old English: verb movement to Infl. The Linguistic Review 10. 5-35.

Pintzuk, Susan. 1999. Phrase Structures in Competition: Variation and Change in Old English Word Order. New York: Garland.

Pintzuk, Susan \& Eric Haeberli. 2008. Structural variation in Old English root clauses. Language Variation and Change 20. 367-407.

Poletto, Cecilia. 2006. Parallel phases: A study on the high and low left periphery of Old Italian. In Mara Frascarelli (ed.), Phases of Interpretation, 261-294. Berlin: de Gruyter. 
Poletto, Cecilia. 2011. Topics (and focus) in Old Italian Syntax. Manuscript.

Quirk, Randolph, Sidney Greenbam, Geoffrey Leech \& Jan Svartvik. 1985. A Comprehensive Grammar of the English Language. London: Longman.

Radford, Andrew. 2004. Minimalist Syntax: Exploring the Structure of English. Cambridge: Cambridge University Press.

Roberts, Ian G. 1993. Verbs and Diachronic Syntax: A Comparative History of English and French. Dordrecht: Kluwer.

Salvesen, Christine Meklenborg. 2011. Stylistic Fronting and Remnant Movement in Old French. In Janine Berns, Haike Jacobs \& Tobias Scheer (eds.), Romance Languages and Linguistic Theory 2009 Selected papers from 'Going Romance' Nice 2009, 323-342. Amsterdam: John Benjamins.

Thurneysen, Rudolf. 1892. Zur Stellung des Verbums im Altfranzösischen. Zeitschrift für Romanische Philologie XVI. 289-307.

Traugott, Elizabeth Closs. 1992. Syntax. In Richard M. Hogg (ed.), The Cambridge History of the English Language, 168-289. Cambridge: Cambridge University Press.

Vance, Barbara S. 1997. Syntactic Change in Medieval French: Verb-Second and Null Subjects. Dordrecht: Kluwer.

Walkden, George. To appear. Verb-third in early West Germanic: A comparative perspective. In Theresa Biberauer \& George Walkden (eds.), Syntax over Time: Lexical, Morphological and Information-structural Interactions, Oxford: Oxford University Press.

Walkden, George Lee. 2012. Syntactic Reconstruction and Proto-Germanic. Cambridge: Cambridge University dissertation.

Zwicky, Arnold. 1977. On clitics. Indiana University Linguistics Club Bloomington. 
AUTHOR CONTACT INFORMATION

Christine Meklenborg Salvesen

Department of Literature, Area Studies and European Languages

University of Oslo

Norway

c.m.salvesen@ilos.uio.no

Kristin Bech

Department of Literature, Area Studies and European Languages

University of Oslo

Norway

kristin.bech@ilos.uio.no 